\title{
Tourists Perception about Tourist Attraction of Waterfall in the Village of Senaru District of Bayan North Lombok
}

\author{
I Wayan Pantiyasa*, Gede Yoga Kharisma Pradana, Original Bertuyes Nale \\ International Bali Institute of Tourism, Indonesia
}

Copyright $\mathrm{O} 2018$ by authors, all rights reserved. Authors agree that this article remains permanently open access under the terms of the Creative Commons Attribution License 4.0 International License

\begin{abstract}
A waterfall in the village of Senaru became an attractive tour that offers natural attraction of waterfall, and also unique and interesting artificial attraction. This fact can potentially attract visitors. But the data of tourists visitation in the last 5 (five) years had fluctuations. It is necessary to research on tourists' perception about waterfall in the village of Senaru. The purpose of this research is to know the tourists perception about attraction, amenities, accessibilities and ancillary. Respondents are visitors and about 60 visitors were chosen by random. This research uses questionnaire as instrument that consists of attraction, amenity, accessibilities and ancillary aspect. Data then analyze using descriptively. The results show that the perception of tourists are average of respondents having good perception on aspects of the attractions of comfort and hygiene, the diversity and security in tourism area, on aspects of accessibilities of road quality, affordability of public transportation and road directions, on aspects of amenities of parking security and capacity, lodging, the capacity of the place of worship, restaurant, gazebo, and on ancillary aspect of officers speed in ticket sales, officers ability and civility on handling of complaints and officers politeness in the area of a waterfall.
\end{abstract}

Keywords Perception, Attraction, Amenities, Accessibilities, Ancillary, Senaru Waterfall

\section{Introduction}

\subsection{Background}

Tourism development occurs in every country in the world. Pendit [1] said Tourism sector is one alternative to help the development of an area and generate income for the country.

The potential of tourism in Lombok Island is spread in almost every district. The unique characteristics and distinctive became one tourist attraction of Lombok Island. This makes the Lombok Island has tour packages ranging from the coast, mountains, art and culture, architecture, crafts, food, until modern recreation such as shopping, and vacation in the small islands around the island of Lombok.

One tourist attraction on the Lombok Island is the Waterfall in Village of Senaru of District of Bayan of North Lombok Regency province. The area has three waterfalls in one place, namely Sendang Gile, Tiu Kelep and Batara lajang. Waterfall in Village of Senaru offers attractions such as the beautiful and natural waterfall.

Potential tourism of Senaru certainly has a positive impact on tourist visits. However, based on statistics, the data of tourist visits rate to the village of Senaru gained from the Department of Culture and Tourism of North Lombok Regency in the last 5 years has fluctuated which in 2010 decreased by $12 \%$ (607.141 tourists). In the year 2011 slightly increased by $0.33 \%$ (609.141 tourists). In the year 2012 again decreased by $7.3 \%$ (564.747 tourists). Furthermore, the number then dropped dramatically in 2013 amounted to $42.84 \%$ (322.764 tourists), and in 2014 there was an increase of $1.12 \%$ (362.554 visitors). The ratio of tourist visits to Senaru village for five years can be seen in the following this table. 
Table 1. Tourist Visits to the Senaru Village

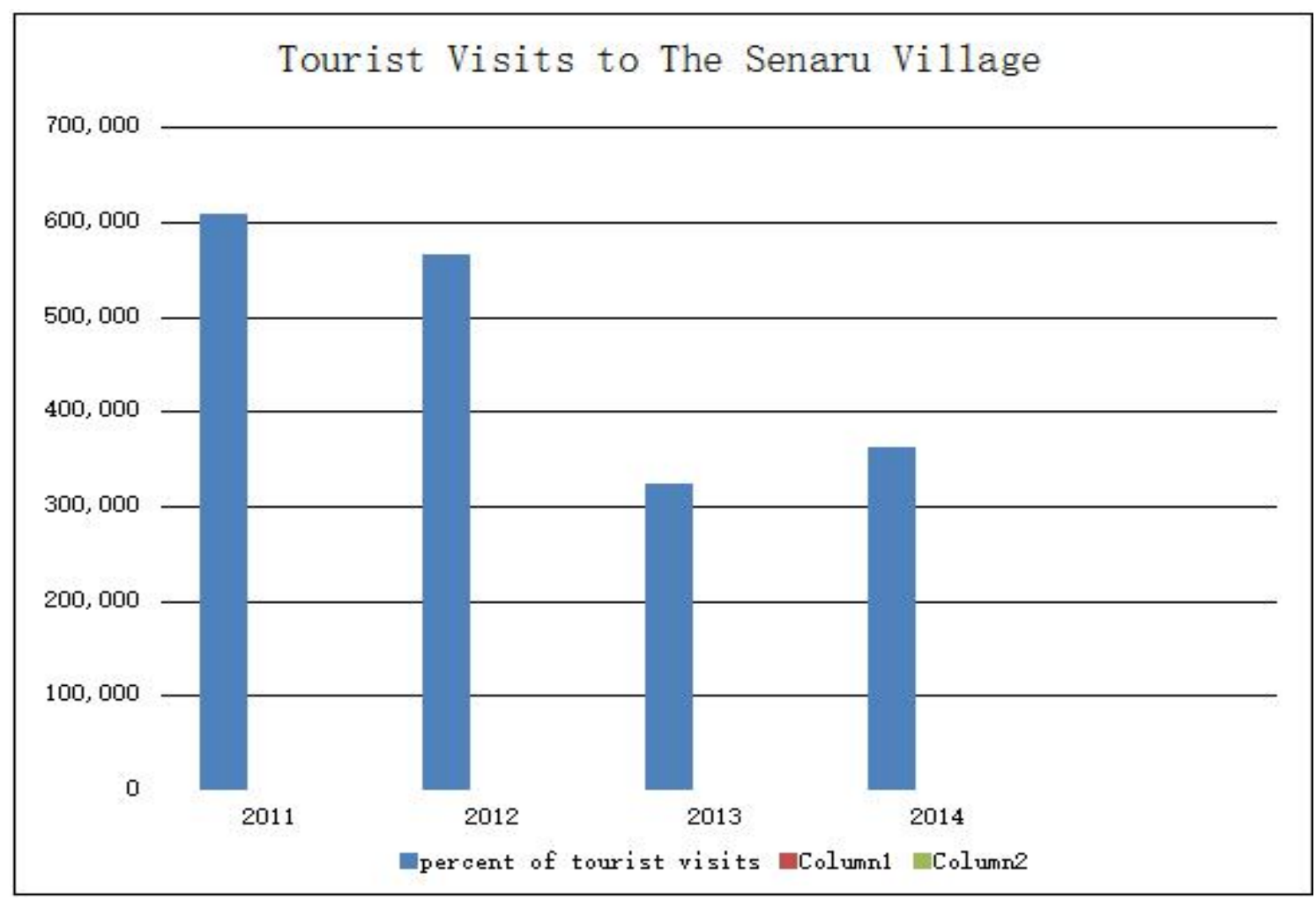

Based on the exposure presented by Gunawan, a waterfall in the village of Senaru lack of attention shown by the lack of facilities such as bins and toilets, as well as the lack of hygiene, under these conditions, it is need to know the perception of tourists to the Tourism Destination Region titled "Tourist Perception about Tourist Attractions of Waterfall in the Village of Senaru, District of Bayan, North Lombok Regency.

\subsection{Research Problem}

The research problem is how about the tourist perception to water fall destination in Senaru village seen from tourist attraction, amenities, accessibility and ancillaries dimension.

\subsection{Research Objective}

The Research Objective is to know the tourist perception to water fall destination in the village of Senaru seen from tourist attraction, amenities, accessibility and ancillaries dimension.

\section{Literature Review}

\subsection{Tourist Perception}

Rangkuti in Negara [2] said that perception is identified as a process for one to choose, to organize, and to interpret the stimulus accepted through one's five senses to be a meaning. Besides, the meaning of perception process is influenced by one's past experience.

Rakhmat [3] mentions that perception is the result of one's experience about object, moment or relations by concluding information dan interpret message.

According Prasetijo and Ihalauw [4] perception is a process of one's sensation which is sort and select, then manage and interpreted.

Rakhmat [3] said it's clear that perception and sensation has a relationship. Sensation is part of perception. However, interpret five senses information meaning involve attention, expectation, motivation and memory in addition to sensation

The experts above have different opinion on perception. However, we can conclude that perception is a process of giving meaning, interpretation of stimulus and sensation that is accepted by the individual according to one's characteristic.

According to Damayanti in Prasilika [5] the process to form perception is:

1) Stimulus acceptance process

This is the process when one accept stimulus from all sources through one's senses and give an appropriate response according to marking and meaning to the stimulus.

2) Stimulus selection process

One will sort and select the stimulus to further process. 
3) Organizing process

The accepted stimulus will be organized in an appropriate form according to the accepted stimulus.

4) Interpretation process

One will interpret the accepted data by various methods. Perception will be happened after the data is interpreted. Perception gives meaning to all data which influence interpretation, such as:

a) One's values or opinion is called by perception equipment.

b) Perception protection, if the accepted data or stimulus is in contradiction with one's values or beliefs, so one will do perception protection by refusing the accepted data, modify it, attitude justification and belief to the accepted data.

On the perception process, all stimuli will come the senses but they have different attraction. There are some factors that influence perception. According to Setiadi [6] the factors influence perception are sight and accepted target and the situation perception taken place. The reaction of the stimuli will be influenced by one's characteristic who see it. Perception will be influenced by:

1) Attitude: It will influence one's positive or negative response.

2) Motivation: It pushes one to do something.

3) Interest: It differs one's marking to certain object and underlie one's favorite or not to the object.

4) Past experience: It influences one's perception because one usually concludes according to something one ever seen and heard.

5) Expectation: It influences one's perception to make a decision. One will tend to refuse idea, invitation or offer that are not appropriate to one's expectation.

6) Target: It will influence one's sight and perception.

7) Situation: Situation surrounding us will influence one's perception. Different perception will be produced when one sees same target but in different situation.

According to Mulyana [7], there are two perceptions:

1) Perception to object (physical environment and human being) Perception to human being is more difficult and complex, because it is dynamic.

2) Social perception

It is a process to find the meaning of social objects and events happening surround us. One has different interpretation to the reality surround. Some social perception principles according to Mulyana [7] are:

1. Perception based on experience

It is one's perception to object or event and one's reaction based on one's experience and prior learning relates to human, object, or similar event.

2. Selective perception

Every human often gets sense stimuli all at once, so it could be selective to choose the important stimuli. Attention is the main factor to decide which selectivity to the stimuli.

3. Assumptions perception

It is happened because the accepted data about the object is not always complete. Perception goes to the conclusion.

4. Evaluative perception

One will interpret the message as a truth. However, the sense and perception decides so one will be doubt. One has to some accurate evaluation to get the truth level.

5. Contextual perception

It has strong influence to make a perception of an object. The context in seeing human, object or event will influence cognitive structure, principle expectation that is the similarity or closeness and completeness and one tends to give perception to the stimuli or event depends on the structure and background.

\subsection{Tourism Attraction}

Based on Indonesia Law No 10 in 2009 on Tourism in chapter I verse 5 is explained that Tourism Attraction is everything which has unique, attractive and value in variety of nature, culture and man-made for tourist destination. According to Pradana and Pantiyasa [8], tourists are interested them because it can gives a different vibration and freshness that reinforces of event at the tourism destination.

Tourism Destination is 'something' in tourism destination which offers/provides to tourists to be seen and can be a magnet to attract them, Gunn in Warpani and Indira [9] says Tourism Attraction is something can be seen, done, bought, or enjoyed in tourism destination. In another source, Pitana [10] classifies tourism development source, such as natural source, culture source, special interest source and human source.

\subsection{Nature-Based Tourism}

Nature-based tourism is all kind of various and unique natural tourism attraction according to Government Law No 50 Year 2011 about National Tourism Development Main Plan. Nature-based tourism is:

a) Based on the potential of various and unique nature in marine, such as: seashore area and coastal that having maritim, water and seabed on certain distance.

b) Based on the potential of various and unique nature in mainland, such as: mountains and forest/national park/natural tourism park, jungle, river and lake, plantation, agriculture, special natural landscape, as cave, carst, desert and so on.

According to Sunaryo [11], nature-based tourism is tourism which is developed based on the beauty and the uniqueness of nature, like white sand beach, sea wave and the access to see sunrise and sunset, coral reef and fish in 
sea, beautiful scenery in lake, volcano, flora and fauna in forest and i clean water of river, water fall and its cliff and so on.

Nature-based tourism is a recreation activity and tourism which is used natural potency, naturally or after cultivation, so it possibly makes the tourist to get fresh spiritual and physical freshness, knowledge, experience and grow the inspiration and love to the nature.

According to Pradana and Parwati [12], every truth of value is defined as common property of the existence. Based on the meanings of nature-based tourism above, the researcher conclude that the value system inherent the natural tourism as a recreation activity which is used natural potency, naturally or after cultivation can be a common property or strengthen the existence of prestige and entertaint them, so there is attraction in that place.

\subsection{The Concept of $4 \mathrm{~A}$ in Tourism}

The important component in tourism industry is 4A as stated by Cooper [13] Attractions, Accessibility, Amenities and Ancillarary Services.

\section{1) Attractions}

Ridwan [14] Attraction is anything which is attracted tourist, such as: nature, culture, social, historic building. According to Buhalis [15] attraction is an object which can be visited by the tourist to see, to use or to enjoy it.

There are three attraction factors in a tourism destination, as pull factor, push factor and distance pull. The attractiveness, the uniqueness and the type of the attraction are kind of pulling factor of a tourism destination which can attract tourist to visit.

A tourism destination has a push factor if it is able to offer the tourist in distance scope to visit. It means it is able to attract local and international tourist.

Attraction is the most important thing to give encouragement to the tourist to visit, so attraction is used as the introduction step where the product life cycle system it is introduced or marketed in the product introduction. Then in growth step, the promotion system will be effective where the need to visit is grown.

\section{2) Amenities}

Anything which provides all tourists' needs during their time in a destination, it provides accommodations, restaurants, local transport and communication tools.

\section{3) Accessibility}

The availability of accessibility relates to tourist's expense, the velocity and comfortable which are got by the tourist. The components are:

1) Infrastructure like roads, parking lots, airports, railways, harbors, land and sea track.

2) The velocity to reach public transportation.

3) Route, service frequent, price and cost.
4) Government regulation: the scope of control regulation scope toward transport operational.

4) Ancillary

Ancillary and human resource support tourism, such as tourist information center, service and regulation regarding the tourism object.

\section{Methodology}

\section{Research Sites}

This research was conducted at the waterfall in the village of Senaru, District of Bayan, North Lombok Regency. There are three waterfalls namely Sendang Gile, Tiu Kelep and Batara Lajang waterfall.

\section{Population}

In this study the population is entire domestic and foreign tourists who visit the waterfall in Village of Senaru.

\section{Samples}

The sampling technique used in this study is the judgmental sampling technique (withdrawal quota sample basis) and proposed 37 domestic tourists and 23 foreign tourists who visit the waterfall in the village of Senaru. Thus, the total number of samples is 60 respondents.

\section{Data Source}

The primary data obtained by observation, interviews and questionnaires to the tourists visiting the waterfall in the village of Senaru on the perception of tourists to the attractions, accessibility, amenity and ancillary.

\section{Data Collection Techniques}

Data were collected using the questionnaire of travelers' perception to the attractions, accessibility, ancillary and amenity of the waterfall in the village of Senaru.

The questionnaire in this study uses a likert scale. This technique is filled with coding or scoring, and is translated into:
a) Scores 1: Not Good
b) Scores 2: Less Good
c) Scores 3: Good
d) Score 4: Very Good

\section{Data Analysis Techniques}

Validity Test

Validity test performed on each question from a variable to determine the extent of the accuracy and precision of the 
questionnaire. Validity test is done by using Cronbach's Alpha test.

\section{Reliability Test}

Reliability test is performed to determine the consistency of measurement tools (questionnaires). Reliability test in this study conducted using Pearson Correlation test.

\section{Descriptive Statistics}

Descriptive statistics were performed by analyzing observational data and describe the collected data as it is without making generalizations. In this study used the average value or mean and the percentage that will be displayed in the form of tables and histogram

$$
\bar{x}=\frac{x_{1}+x_{2}+\ldots+x_{n}}{n}
$$

Information:

$\mathrm{x}=$ The average count

$\mathrm{xi}=$ the value of the $\mathrm{i}$-th sample

$\mathrm{n}=$ number of samples

Table 2. Criteria for Tourist Perception Against Tourist Attraction of Waterfalls in The Village of Senaru

\begin{tabular}{c|c}
\hline Interval Score & Criteria \\
\hline $3,26-4,00$ & Very Good \\
\hline $2,51-3,25$ & Good \\
\hline $1,76-2,5$ & Less Good \\
\hline $1,0-1,75$ & Not Good \\
\hline
\end{tabular}

Based on the above table, we can be seen that the best criteria for tourist perception against tourist attraction of waterfalls in the village of Senaru is at interval score 3,26-4. The worst criteria for tourist perception against tourist attraction of waterfalls in the village of Senaru is range score 1-1.75. While the interval score of 1.76-2.5 and 2.51-3.25 interval score classified less good and good criteria.

\section{Results and Discussion}

\section{Tourist Attraction Perceptions of Respondents}

Respondent's perceptions (RP) against tourist attraction of waterfall in the village of Senaru, District of Bayan, North Lombok Regency can be seen in Table 3 below:

Table 3. Perception of Respondents Againts Travel Attractions of Waterfall in the Village of Senaru District, Bayan North Lombok Regency

\begin{tabular}{|c|c|c|c|}
\hline No & Indicator & Mean & Criteria \\
\hline 1 & Cleanliness & 3,20 & Good \\
\hline 2 & Diversity of attraction & 2,77 & Good \\
\hline 3 & Regional security & 3,22 & Good \\
\hline 4 & Quality of Road & 2,85 & Good \\
\hline 5 & Affordability of Public Transport & 2,62 & Good \\
\hline 6 & Road directions & 2,65 & Good \\
\hline 7 & Capacity of the parking lot & 3,12 & Good \\
\hline 8 & Security of parking lot & 3,17 & Good \\
\hline 9 & Toilet Cleanliness & 2,27 & Less Good \\
\hline 10 & Number of toilets & 1,75 & Not Good \\
\hline 11 & Rinse and wash facilities & 1,72 & Not Good \\
\hline 12 & Condition of information Center & 2,27 & Less Good \\
\hline 14 & Restaurant & 2,93 & Good \\
\hline 15 & Availability of trash & 2,57 & Less Good \\
\hline 16 & Gazebo conditions and seating & 3,05 & Good \\
\hline 17 & Souvenir shop & 2,42 & Less Good \\
\hline 18 & Lodging facilities & 2,72 & Good \\
\hline 19 & Officer Speed in ticket sales & 2,83 & Good \\
\hline 20 & $\begin{array}{l}\text { Officers ability and courtesy in the } \\
\text { handling of complaints }\end{array}$ & 2,75 & Good \\
\hline 21 & $\begin{array}{c}\text { Officers Courtesy while in the waterfall } \\
\text { area }\end{array}$ & 2,65 & Good \\
\hline 22 & $\begin{array}{l}\text { Officers willingness to help in time of } \\
\text { trouble }\end{array}$ & 2,37 & Less Good \\
\hline \multicolumn{2}{|c|}{ Total } & 58,5 & \\
\hline \multicolumn{2}{|r|}{ Mean } & 2,66 & Good \\
\hline
\end{tabular}

Table 4. Perception of Respondents to Tourist Attractions Waterfall at Senaru Village, District Bayan, North Lombok

\begin{tabular}{c|c|c|c|c|c|c|c|c|c|c}
\hline $\mathbf{1}$ & \multicolumn{2}{|c|}{$\mathbf{2}$} & \multicolumn{2}{|c|}{$\mathbf{3}$} & \multicolumn{2}{c|}{$\mathbf{4}$} & \multicolumn{2}{|c|}{$\mathbf{5}$} & $\mathbf{6}$ & $\mathbf{7}$ \\
\hline \multirow{2}{*}{ Attraction } & \multicolumn{2}{|c|}{ Very Good } & \multicolumn{2}{|c|}{ Good } & \multicolumn{2}{c|}{ Less Good } & \multicolumn{2}{|c|}{ Total } & \multirow{2}{*}{ Mean } & \multirow{2}{*}{ Criteria } \\
\cline { 2 - 12 } & $\mathbf{n}$ & $\mathbf{\%}$ & $\mathbf{n}$ & $\mathbf{\%}$ & $\mathbf{n}$ & $\mathbf{\%}$ & $\mathbf{n}$ & $\mathbf{\%}$ & & \\
\hline Cleanliness & 17 & 28,3 & 38 & 63,4 & 5 & 8,3 & 60 & 100 & 3,20 & Good \\
\hline Attractions Diversity & 6 & 10 & 34 & 56,7 & 20 & 33,3 & 60 & 100 & 2,77 & Good \\
\hline Area Security & 17 & 28,3 & 39 & 65 & 4 & 6,7 & 60 & 100 & 3,22 & Good \\
\hline
\end{tabular}


Rp of cleanliness are, as much as $28.3 \%$ or 17 people have a very good perception, 38 people or $63.4 \%$ have a good perception, and 5 people or $8.3 \%$ have not good perceptions. The mean value or the average of Respondent's perceptions of cleanliness is good, that is equal to 3.20. Meanwhile, respondent's opinions of diversity of attractions are as many as 6 people or $10 \%$ have a very good perception, 34 people or $56.7 \%$ have a good perception, and 20 people or $33.3 \%$ have not good perceptions. The mean value or the average of respondent's perceptions of diversity of attractions is good, that is equal to 2.77. In addition, respondent's perceptions of regional safety of Waterfall are, as much as $28.3 \%$ or 17 people have a very good perception, 39 or $65 \%$ have a good perception and 4 people, or $6.7 \%$ have not good perceptions. The mean value or the average of respondent perceptions of regional safety is good, that is equal to 3.22.

The results showed that the average perception rating of the three aspects of attractions including cleanliness, the diversity of attractions, and regional safety of tourist areas. The results of observations conducted by researchers indicate cleanliness of tourist area of waterfall in the village of Senaru is very well preserved. Road lanes from the parking lot to the location of the waterfall looked clean, including gazebos that can be used by visitors to rest. Similarly, under the waterfall pool looked clean, so many visitors who looked without hesitation into the water for a shower. This is consistent with the results of this study, in which the respondent's perception of cleanliness at tourist sites of waterfall in the village Senaru is good.

On focus to the diversity of attractions, a tourist area of waterfall in the village of Senaru, not only showing the natural beauty of waterfalls, mountains and rivers, but also the object of artificial attractions. This means that this mosque has been aged more than 300 years. Two hundred meters from the mosque there is a traditional house of Karang Bajo. The house is occupied by the Toak Lokak (elders), stakeholders and the local traditional leaders.

In the customs hall of Senaru, visitors can see the unique traditional houses. The floors are made of clay, the fence made of bedek and thatched of roofs. Its citizens were friendly and welcome to tourists who come. This area is also lush and beautiful, some coffee trees belonging to residents make this place more shady. Visitors can also relax to the sprawling bangket bayan and adjacent to the indigenous forests to see the beautiful scenery in the paddy fields.

There are three waterfalls in the village of Senaru, however only two waterfalls which were developed as a tourist area by the Department of Tourism of North Lombok Regency, namely Tiu Kelep waterfall and Sendang Gile waterfall. Other waterfalls are Batara Lajang waterfall, but this waterfall is not used as a tourist attraction. Tiu Kelep waterfall position located between of Sendang Gile and Batara Lajang waterfall.

Sendang Gile is under Tiu Kelep waterfall, where the water falling of Tiu Kelep waterfall going over the sloping cliff with green mossy on it and forming Sendang Gile waterfall. While the Batara Lajang waterfall located upstream, above the Tiu Kelep waterfall. Batara Lajang waterfall is very difficult to achieve because of the steep and remote terrain. This is why Batara Lajang waterfall was not opened as a tourist attraction.

Tiu Kelep waterfall has 30 meters of height and is one of several waterfalls at the foot of Mount Rinjani. Tiu Kelep waterfall name is taken from the Sasak language, "tiu" means the pool, while the "kelep" means fly. To go to the location of the waterfall, tourists have to walk about 30 minutes from the entrance. During the journey visitors will be treated to views of the tropical rain forest that is still green and also clear streams. Tiu Kelep waterfall is one of the themed Waterfall attractions in Lombok after Sendang Gile. This waterfall is located in the area of Mount Rinjani National Park with source water comes from Segara Anak Lake on the top of Mount Rinjani. From the entrance in the village of Senaru, the journey begins with trecking past mossy stairs and steep. Once past the stairs, turn to the right will be heading of Tiu Kelep waterfall, while a left turn will lead to Sendang Gile waterfall.

The Person in charge of the waterfall in the village of Senaru appears to give concern to the aspect of security in tourist areas. This is demonstrated by the various warning directions, as well as the construction of stairs climbed equipped grip and safety fence. While in the location of the waterfall pool shower, water depths average of only 1 meter as well as the bottom of the pool that is soft and flat, relatively safe used to swim. However from the observations of researchers, there are spots that actually harmful for children, but not installed guardrails and warning directions of danger. The vulnerable points of which the end of the steep sloping expanse of land, the location close to the point above the waterfall pool and the woods on either side of the trail to the waterfall.

From interviews with respondents, some suggestions for improving the attractions aspect in the waterfall area in village of Senaru is building facilities for children to play, as well as building a safety limit or warning directions in waterfall location thus avoiding the access of children to a dangerous area.

\section{Accessibility}

The RP of the road's quality to the tourist area is, as much as $10 \%$ or 6 people have a very good perception, 39 or $65 \%$ have a good perception and 15 or $25 \%$ had an not good perception. The mean value or the average of respondent's perceptions of the quality of road is good, that is equal to 2.85. In additions, the opinions of respondents on the affordability of public transport are as many as 5 people or $8.3 \%$ have a very good perception, 27 or $45 \%$ have a good perception and 28 people or $46.7 \%$ have not good perceptions. The mean value or the average 
of respondent's perceptions on the affordability of public transport is good, that is equal to 2.62. While the respondents perception of in the manual aspects (driving directions) of the road to the tourist area is as much as $8.3 \%$ or 5 people have a very good perception, 30 people or $50 \%$ have a good perception, 24 people or $40 \%$ have not good perceptions, and 1 person or $1.7 \%$ have a perception is not very good. The mean value or the average of respondents' perception of the manual aspects (driving directions) of the road is good, that is equal to 2.65 .

In the aspect of accessibility, the average respondent's perception of site accessibility which includes road conditions, the affordability of public transport, as well as driving directions are good. Along the $35 \mathrm{~km}$ to tourist sites, visitors will pass through a paved road class III A with good quality with directions pointing the direction to travel locations in the village of Senaru. This may explain the perception of respondents were either to road conditions and diving directions. But most respondents perceive that the affordability of public transport is still lack. From Mataram, the village can be reached within 2.5 - 3 hours one-way trip. There is no regular public transportation that can take tourists to the location of Senaru, but in Mataram and Senggigi, many car rental service providers who can deliver travelers to the location of the village of Senaru with prices ranging Rp. 700.000 to Rp. 1.000 .000 .

Table 5. Perception of Respondents to Accessibility of Waterfall Tourism of Senaru Village, Bayan Sub District, North Lombok Regency

\begin{tabular}{|c|c|c|c|c|c|c|c|c|c|c|c|c|}
\hline 1 & \multirow{2}{*}{\multicolumn{2}{|c|}{$\begin{array}{c}2 \\
\text { Very } \\
\text { Good } \\
\end{array}$}} & \multirow{2}{*}{\multicolumn{2}{|c|}{$\begin{array}{c}3 \\
\text { Good }\end{array}$}} & \multirow{2}{*}{\multicolumn{2}{|c|}{$\begin{array}{c}4 \\
\text { Less Good }\end{array}$}} & \multirow{2}{*}{\multicolumn{2}{|c|}{$\begin{array}{c}5 \\
\text { Not Good }\end{array}$}} & \multirow{2}{*}{\multicolumn{2}{|c|}{$\begin{array}{c}6 \\
\text { Total } \\
\end{array}$}} & 7 & 8 \\
\hline \multirow{2}{*}{ Accessibility } & & & & & & & & & & & \multirow{2}{*}{ Mean } & \multirow{2}{*}{ Criteria } \\
\hline & $\mathbf{n}$ & $\%$ & $\mathbf{n}$ & $\%$ & $\mathbf{n}$ & $\%$ & $\mathbf{n}$ & $\%$ & $\mathbf{n}$ & $\%$ & & \\
\hline Quality of the Road & 6 & 10 & 39 & 65 & 15 & 25 & 0 & 0 & 60 & 100 & 2,85 & Good \\
\hline $\begin{array}{l}\text { Affordability of } \\
\text { Public Transport }\end{array}$ & 5 & 8,3 & 27 & 45 & 28 & 46,7 & 0 & 0 & 60 & 100 & 2,62 & Good \\
\hline Street sign & 5 & 8,3 & 30 & 50 & 24 & 40 & 1 & 1,7 & 60 & 100 & 2,65 & Good \\
\hline
\end{tabular}

\section{Amenity}

Table 6. Perception of Respondents to Waterfall Amenitas Village Senaru Bayan Sub-District, North Lombok Regency

\begin{tabular}{|c|c|c|c|c|c|c|c|c|c|c|c|c|}
\hline \multirow{3}{*}{ Amenities } & & & \multirow{2}{*}{\multicolumn{2}{|c|}{$\begin{array}{c}3 \\
\text { Good } \\
\end{array}$}} & \multirow{2}{*}{\multicolumn{2}{|c|}{$\begin{array}{c}4 \\
\text { Less Good }\end{array}$}} & \multirow{2}{*}{\multicolumn{2}{|c|}{$\begin{array}{c}5 \\
\text { Not Good }\end{array}$}} & \multirow{2}{*}{\multicolumn{2}{|c|}{$\begin{array}{c}6 \\
\text { Total } \\
\end{array}$}} & \multirow{3}{*}{$\begin{array}{c}7 \\
\text { Mean }\end{array}$} & \multirow{3}{*}{$\begin{array}{c}8 \\
\text { Criteria }\end{array}$} \\
\hline & \multicolumn{2}{|c|}{ Very Good } & & & & & & & & & & \\
\hline & $\mathbf{n}$ & $\%$ & $\mathbf{n}$ & $\%$ & $\mathbf{n}$ & $\%$ & $\mathbf{n}$ & $\%$ & $\mathbf{n}$ & $\%$ & & \\
\hline Parking capacity & 18 & 30 & 31 & 51,7 & 11 & 18,3 & 0 & 0 & 60 & 100 & 3,12 & Good \\
\hline $\begin{array}{c}\text { Security of the } \\
\text { parking lot }\end{array}$ & 18 & 30 & 35 & 58,3 & 6 & 10 & 1 & 1,7 & 60 & 100 & 3,17 & Good \\
\hline $\begin{array}{l}\text { Cleanliness of the } \\
\text { toilet }\end{array}$ & 2 & 3,3 & 16 & 26,7 & 38 & 63,3 & 4 & 6,7 & 60 & 100 & 2,27 & Less Good \\
\hline Total of toilets & 1 & 1,7 & 5 & 8,3 & 32 & 53,3 & 22 & 36,7 & 60 & 100 & 1,75 & Not Good \\
\hline $\begin{array}{l}\text { Laundry wash } \\
\text { facility }\end{array}$ & 0 & 0 & 6 & 10 & 31 & 51,7 & 22 & 36,7 & 60 & 100 & 1,72 & Not Good \\
\hline $\begin{array}{l}\text { The condition of } \\
\text { the information } \\
\text { center }\end{array}$ & 2 & 3,3 & 16 & 26,7 & 38 & 63,3 & 4 & 6,7 & 60 & 100 & 2,27 & Less Good \\
\hline $\begin{array}{l}\text { The capacity of } \\
\text { places of worship }\end{array}$ & 2 & 3,3 & 34 & 56,7 & 22 & 36,7 & 2 & 3,3 & 60 & 100 & 2,60 & Good \\
\hline Restaurant & 10 & 16,7 & 36 & 60 & 14 & 23,3 & 0 & 0 & 60 & 100 & 2,93 & Good \\
\hline $\begin{array}{c}\text { The availability } \\
\text { of trash }\end{array}$ & 2 & 3,3 & 32 & 53,3 & 24 & 40 & 2 & 3,3 & 60 & 100 & 2,57 & Less Good \\
\hline $\begin{array}{c}\text { Condition of } \\
\text { gazebo, seating }\end{array}$ & 19 & 31,7 & 25 & 41,7 & 16 & 26,7 & 0 & 0 & 60 & 100 & 3,05 & Good \\
\hline Souvenir Shop & 2 & 3,3 & 24 & 40 & 31 & 51,7 & 3 & 5 & 60 & 100 & 2,42 & Less Good \\
\hline $\begin{array}{l}\text { Accommodation } \\
\text { facilities }\end{array}$ & 8 & 13,3 & 29 & 48,3 & 21 & 35 & 2 & 3,3 & 60 & 100 & 2,72 & Good \\
\hline
\end{tabular}


Respondent's opinions of the capacity of the parking lot are as much as $30 \%$ or 18 people had a very good perception, 31 people or $51.7 \%$ have a good perception, and 11 people or $18.3 \%$ have not good perceptions. The mean value or the average of Respondent's perception about the capacity of the parking lot is good, that is equal to 3.12. Meanwhile, Respondent's perception of the security of a parking lot is as many as 18 people or $30 \%$ had a very good perception, 35 people or $58.3 \%$ have a good perception, 6 , or $10 \%$ have not good perceptions and 1 person or $1.7 \%$ has a perception very not good. The mean value or the average of respondent's perception about security of a parking lot is good, that is equal to 3.17 . In addition, respondent's perceptions of cleanliness of the toilet are as much as $3.3 \%$ or 2 people have a very good perception, 16 people or $26.7 \%$ have a good perception, 38 people or $63.3 \%$ have not good perceptions and 4 people or $6,7 \%$ have the perception is not very good. The mean value or the average of respondent's perceptions of cleanliness of the toilet is good, that is equal to 2.27. Meanwhile, respondent's opinions of the number toilets are as much as $1.7 \%$ or 1 person has a very good perception, 5 people or $8.3 \%$ have a good perception, 32 people or $53.3 \%$ had not good and 22 people or $36.7 \%$ have the perception is not very good. The mean value or the average of respondent's perceptions about the number of toilets is not very good, that is equal to 1.75. In addition, the opinions of respondents of rinse and washing facility are as many as 6 people or $10 \%$ have a good perception, 31 people or $51.7 \%$ have not good perceptions and as much as $36.7 \%$ or 22 people have a perception is not very good. The mean value or the average of respondents' perceptions of rinse and washing facility to rinse and washing facilities is not very good, that is equal to 1.72 .

The opinions of respondents of information center condition are as much as $3.3 \%$ or 2 people have a very good perception, 16 people or $26.7 \%$ have a good perception, 38 people or $63.3 \%$ have not good perceptions and the 4 or $6,7 \%$ have a perception is not very good. The mean value or the average of respondents' perceptions of information center condition is not good, that is equal to 2.27. Meanwhile, the perceptions of respondents about the capacity of the worship place as many as 2 people or $3.3 \%$ have a very good perception, 34 people or $56.7 \%$ have the perception of good, 22 people or $36.72 \%$ have not good perceptions and 2 or $3.3 \%$ have a perception is not very good. The mean value or the average of respondents' perceptions about the capacity of the worship place is good, that is equal to 2.60. In addition, the opinions of respondents about the existence of the restaurant as much as $16.7 \%$ or 10 people have a very good, 36 or $60 \%$ have a good perception and 14 people or $23.3 \%$ have not good perceptions. The mean or average respondent is good, that is equal to 2.93. In addition, Respondents' perceptions of the availability of the trash as many as 2 people or 3.3\% have a very good perception, 32 people or $53.3 \%$ have a good perception, 24 people or $40 \%$ have not good perceptions and two people or $3.3 \%$ have the perception is not very good. The mean value or the average respondent is not good, that is equal to 2.57. Meanwhile, Respondents' perceptions of gazebo conditions and seating are as much as $31.7 \%$ or 19 people have a very good perception, 25 people or $41.7 \%$ had good, 16 people or $26.7 \%$ less than excellent. The mean value or the average of respondents' perceptions of gazebo conditions and seating is not good, that is equal to 3.05. Meanwhile, Respondent's opinions of souvenir shop are as many as 2 people or $3.3 \%$ have a very good perception, 24 people or $40 \%$ have a good perception, 31 people or $51.7 \%$ have not good perceptions and 3 or $5 \%$ have a perception is not very good. The mean value or the average of respondents' perceptions of souvenir shop is not good, that is equal to 2.42 .

The RP of lodging facilities are as much as $13.3 \%$ or 8 people have a very good perception, 29 people or $48.3 \%$ have a good perception, 21 or $35 \%$ had a poor perception and 2 or $3.3 \%$ have perception is not very good. The mean value or the average of respondents' perceptions of lodging facilities is good, that is equal to 2.72 .

The results showed that on the amenity aspect, the average of respondent has a very good perception of the number of toilets and washing and rinse facilities. In addition the average perception of respondents have less good to the conditions of information center, cleanliness of toilets, availability of trash, as well as the existence of souvenir shops. The presence of foreign tourists who visit as well as domestic tourists from various regions outside North Lombok Regency, would have an interest to bring souvenirs. Then the central location information is only in the entrance area of Senaru, will be difficult for tourists to get information when it is in the waterfall area, especially for first-time traveler.

In addition, the fact of the waterfall that can be used for swimming will increase the need of visitors on the toilet and place for bathing, washing and rinse. While the respondents' perception of the capacity and security of the parking lot, the capacity of worship places, gazebo, restaurants and lodging facilities are good. There are two options for the visitors who want to stay, firstly in the tourist location, or in Mataram. If visitors want to stay in the area of Senaru, visitors can stay at some homestay available or if they want to stay in Mataram, visitors can choose hotels like Griya Asri Hotel, Bidari Hotel and Lombok Plaza Hotel.

Some suggestions from respondents relating to amenity aspects are increase the number of toilet and shower, also washing and rinse facilities, especially in the area of waterfall, improving the cleanliness of toilet, build an information center at the area of the waterfall as well as some gazebo larger so that it can be used by visitors to take rest especially in rainy conditions. 
Ancillary

Table 7. Perception of Respondents to Ancillary Waterfall Tour of Senaru Village, Bayan Sub District, North Lombok Regency

\begin{tabular}{|c|c|c|c|c|c|c|c|c|c|c|c|c|}
\hline 1 & & & & & & & & & & & 7 & 8 \\
\hline \multirow{2}{*}{ Ancillary } & \multicolumn{2}{|c|}{ Very Good } & \multicolumn{2}{|c|}{ Good } & \multicolumn{2}{|c|}{ Less Good } & \multicolumn{2}{|c|}{ Not Good } & \multicolumn{2}{|c|}{ Total } & \multirow{2}{*}{ Mean } & \multirow{2}{*}{ Criteria } \\
\hline & $\mathrm{n}$ & $\%$ & $\mathrm{n}$ & $\%$ & $\mathrm{n}$ & $\%$ & $\mathrm{n}$ & $\%$ & $\mathrm{n}$ & $\%$ & & \\
\hline $\begin{array}{l}\text { Speed attendant } \\
\text { in ticket sales }\end{array}$ & 9 & 15 & 33 & 55 & 17 & 28,3 & 1 & 1,7 & 60 & 100 & 2,83 & Good \\
\hline $\begin{array}{l}\text { Ability and } \\
\text { courtesy of } \\
\text { officers in } \\
\text { handling } \\
\text { complaints }\end{array}$ & 10 & 16,7 & 26 & 43,3 & 23 & 38,3 & 1 & 1,7 & 60 & 100 & 2,75 & Good \\
\hline $\begin{array}{l}\text { Courtesy officer } \\
\text { while in the } \\
\text { waterfall area }\end{array}$ & 4 & 6,7 & 31 & 51,7 & 25 & 41,7 & 0 & 0 & 60 & 100 & 2,65 & Good \\
\hline $\begin{array}{l}\text { The attendant's } \\
\text { attendance helps } \\
\text { when it is } \\
\text { difficult }\end{array}$ & 1 & 1,7 & 22 & 36,7 & 35 & 58,3 & 2 & 3,3 & 60 & 100 & 2,37 & Less Good \\
\hline
\end{tabular}

Respondent's opinions of officer speed in ticket sales are as many as 9 people or $15 \%$ have a very good perception, 33 or $55 \%$ have a good perception, 17 and or $28.3 \%$ have not good perceptions, and 1 person or $1.7 \%$ have perception is not very good. The mean value or the average of Respondent's perception of officers' speed in ticket sales is good, that is equal to 2.83. Meanwhile, The perceptions of respondents of officers ability and courtesy in the handling of complaints is, as much as $16.7 \%$ or 10 people have a very good perception, 26 people or $43.3 \%$ have a good perception, 23 people or $38.3 \%$ have not good perceptions and 1 or $1.7 \%$ of people have a perception is not very good. The mean value or the average of respondents' perceptions of officers' ability and courtesy in the handling of complaints is good, that is equal to 2.75 . The opinions of respondents of officer courtesy while in the waterfall area as many as 4 people or $6.7 \%$ have a very good perception, 31 people or $51.7 \%$ have a good perception and 25 people or $41.7 \%$ have not good perceptions. The mean value or the average of respondents' perceptions of officer courtesy while in the waterfall area is good, that is equal to 2.65 .

While the RP of the officers willingness to help in time of trouble as much as $1.7 \%$ or 1 person has a very good perception, 22 people or $36.7 \%$ have a good perception, 35 people or $58.3 \%$ have not good perceptions, and 2 people or $3.3 \%$ have a perception is not very good. The mean value or the average of respondent's perception of the officers' willingness to help in time of trouble is not good, amounting to 2.37 .

Ancillary aspects which include the officers' speed in ticket sales, the officers capability and courtesy in the handling of complaints as well as a officers courtesy while in the waterfall area, got an average good perception of the respondents. Gate counter located at the entrance of the village of Senaru was large enough to pass by a large size car, so that inflows to the location quite smoothly.

From observations conducted by researchers, did not seem too long queue of vehicles that enter the site's gate. Ticket Service only takes less than one minute for every incoming vehicle.

Some tourists who want to see the sights and attractions in the village of Senaru usually hire a guide who will take a trip around the village. Guides were incorporated in the "Panorama Work". They are ready to take any traveler to see the unique village of Senaru by rate of Rp. 200.000 per person includes custom home of Senaru, Sendang Gile waterfall, Tiu Kelep waterfall, Bayan bangket, Bayan ancient mosque and traditional house of Karang Bajo. From observations of researchers is all the Guides are friendly people and mastered the English language well. This is evidenced by the good perception of respondents about officer hospitality in the location of waterfall.

\section{Conclusions}

Based on the research results can be concluded that the RP against tourist attraction of waterfall in the village of Senaru District of Bayan, North Lombok Regency is as follows:

1. On the variable of Attractions, the average (mean) of the perceptions of respondents about the hygiene aspects are good, that is equal to 3.20 , the diversity of attraction is a good, which was 2.77 and the Regional security is good, that is equal to 3.22 .

2. On the variable of Accessibility, the average (mean) of the opinions of respondents of road quality is a good, that is equal to 2.85 , the affordability of public transport is good, that is equal to 2.62 , and the driving directions is good, that is equal to 2.65 .

3. On the variable of Amenity, the average (mean) of 
respondent's opinions of the parking lot capacity is good, that is equal to 3.12 , the parking security is good, namely 3.17, the cleanliness of the toilet is less good, that is equal to 2.27 , the number of toilets is not good, that is equal to 1.75 , the rinse and washing facilities are not good, that is equal to 1.72 , the condition of the information center is not good, that is equal to 2.27 , the capacity of worship place is good, that is equal to 2.60 , the existence of the restaurant is good, that is equal to 2.93 , the availability of the trash is not good, that is equal to 2.57 , the condition of the gazebo and seating is less good, that is equal to 3.05 , the souvenir shop is less good, that is equal to 2.42 and the lodging facilities is good, that is equal to 2.72 .

4. On the variable of Ancillary, the average (mean) the respondents' perceptions of the officer speed in ticket sales is good, that is equal to 2.83 , on the officers ability and courtesy in the handling of complaints is good, which is 2.75 , the officer courtesy while in the waterfall area is good, that is equal to 2.65 , and the officers willingness to help in time of trouble is not good, that is equal to 2.37 .

\section{Suggestion}

Based on the conclusion that there are some things that can be used as suggestions are:

1) Maintain the cleanliness of tourist sites, the diversity of attractions, regional security, quality of roads, public transport affordability, driving directions to the location, the capacity of the parking lot, parking lot security, the capacity of a worship place, restaurants, gazebo and seating conditions, lodging, officers speed in ticket sales, the officers capability and courtesy in the handling of complaints, as well as officer courtesy while in the waterfall area.

2) Improving the cleanliness of toilets, improving the condition of the information center, increase the availability of trash, the presence of souvenir shops, and increasing officers' willingness to help in time of trouble.

3) Increase the number of toilets and washing and rinse facilities.

\section{REFERENCES}

[1] Pendit NS. Ilmu Pariwisata Sebuah Pengantar Perdana. Jakarta, PT. Pradnya Paramita, 2006.

[2] Negara IMK, W Pantiyasa, Editor. "Persepsi Wisatawan Nusantara Terhadap Kondisi Kepariwisataan Bali". Hospitality Management (3), 2012 for first article. Denpasar, STPBI.

[3] Rakhmat J. Metode Penelitian Komunikasi. Bandung, PT. Remaja Rosdakarya, 2000.

[4] Prasetijo R. and J. J.O.I Ihalauw. Perilaku Konsumen. Yogyakarta, Andi, 2005.

[5] Prasilika T. Studi Persepsi Resiko Keselamatan Berkendara Serta Hubungan Dengan Locus of Control Pada Mahasiswa FKM UI yang mengendarai Motor Tahun 2007. Depok, Universitas Indonesia, 2007.

[6] Setiadi N. Perilaku Konsumen: Konsep dan Implikasinya Untuk Strategi dan Penelitian Pemasaran. Jakarta, Prenada Media, 2013.

[7] Mulyana D. Ilmu Komunikasi Suatu Pengantar. Bandung, PT Rosdakarya, 2000.

[8] Pradana, GYK, W Pantiyasa. "Makotek as a Tourist Attraction in Munggu Village, Badung". Proceeding of International Conference $2^{\text {nd }}$ Tourism, Gastronomy and Tourist Destination. Jakarta, Trisakti, 2018.

[9] Warpani, SP and Indira PW. Pariwisata dalam Tata Ruang Wilayah. Bandung, ITB, 2007.

[10] Pitana IG and IKS Diarta. Pengantar Ilmu Pariwisata. Yogyakarta, Andi, 2009.

[11] Sunaryo B. Kebijakan Pengembangan Destinasi Pariwisata (konsep dan aplikasinya di Indonesia). Yogyakarta, Gava Media, 2013.

[12] Pradana, GYK, Parwati KSM. "Local Wisdom Based SPA Tourism in Ubud Village Of Bali, Indonesia”. RJOAS, 2017, 8(68), 188-196.

[13] Cooper, K. G. The Rework Cycle (a series of three articles): Why Projects Are Mismanaged; How It Really Works ... and Reworks ...; Benchmarks for the Project Manager. PMNETwork Magazine, February 1993 for first two articles; Project Management Journal 24(1) for third article.

[14] Ridwan M. Perencanaan Pengembangan Pariwisata. Jakarta, PT. Sofmedia, 2012.

[15] Buhalis, D. "Marketing the Competitive Destination of the Future”. Tourism Management, 2000, 2(1), 97-116. 